\title{
Revealing of Non-Cultivable Bacteria Associated with the Mycelium of Fungi in the Kerosene-Degrading Community Isolated from the Contaminated Jet Fuel
}

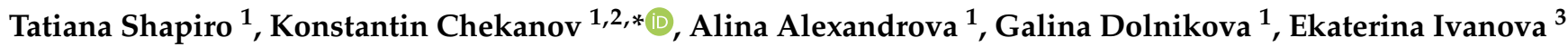 \\ and Elena Lobakova ${ }^{1}$ \\ 1 Faculty of Biology, Lomonosov Moscow State University, 1-12 Leninskie Gory, 119192 Moscow, Russia; \\ tatiananshapiro@gmail.com (T.S.); alina-alex2011@yandex.ru (A.A.); kachekanov@gmail.com (G.D.); \\ elena.lobakova@gmail.com (E.L.) \\ 2 Centre for Humanities Research and Technology, National Research Nuclear University MEPhI, \\ 31 Kashirskoye highway, 115522 Moscow, Russia \\ 3 Department of General and Inorganic Chemistry, National University of Oil and Gas "Gubkin University”, \\ 65 Leninsky Prospekt, 119991 Moscow, Russia; kostya_ne_kostya@mail.ru \\ * Correspondence: chekanov@mail.bio.msu.ru
}

Citation: Shapiro, T.; Chekanov, K.; Alexandrova, A.; Dolnikova, G.; Ivanova, E.; Lobakova, E. Revealing of Non-Cultivable Bacteria Associated with the Mycelium of Fungi in the Kerosene-Degrading Community Isolated from the Contaminated Jet Fuel. J. Fungi 2021, 7, 43. https://doi.org/10.3390/jof70 10043

Received: 26 November 2020 Accepted: 8 January 2021 Published: 11 January 2021

Publisher's Note: MDPI stays neutral with regard to jurisdictional clai$\mathrm{ms}$ in published maps and institutional affiliations.

Copyright: $(\odot 2021$ by the authors. Licensee MDPI, Basel, Switzerland. This article is an open access article distributed under the terms and conditions of the Creative Commons Attribution (CC BY) license (https:// creativecommons.org/licenses/by/ $4.0 /)$.
Abstract: Fuel (especially kerosene) biodamage is a challenge for global industry. In aviation, where kerosene is a widely used type of fuel, its biodeterioration leads to significant damage. Six isolates of micromycetes from the TS- 1 aviation kerosene samples were obtained. Their ability to grow on the fuel was studied, and the difference between biodegradation ability was shown. Micromycetes belonged to the Talaromyces, Penicillium, and Aspergillus genera. It was impossible to obtain bacterial isolates associated with their mycelium. However, 16S rRNA metabarcoding and microscopic observations revealed the presence of bacteria in the micromycete isolates. It seems to be that kerosene-degrading fungi were associated with uncultured bacteria. Proteobacteria, Actinobacteria, Bacteroidetes, and Firmicutes were abundant in the fungal cultures isolated from the TS-1 jet fuel samples. Most genera among these phyla are known as hydrocarbon degraders. Only bacteria-containing micromycete isolates were able to grow on the kerosene. Most likely, kerosene degradation mechanisms are based on synergism of bacteria and fungi.

Keywords: fuel biodamage; fuel biodegradation; microbial community; Talaromyces; Penicillium; Aspergillus

\section{Introduction}

Fuel biodamage leads to a decrease in its quality, as well as corrosion of cutting and fuel tanks during storage and transportation [1-7]. Among a wide range of fuels, different types of gasolines are the most resistant to biodamage, whereas kerosene is the most vulnerable one [6-10]. However, the nature of higher vulnerability of kerosene is not elucidated in detail. In some works, it is speculated that overall hydrocarbon composition and total nitrogen content, as well as physicochemical parameters such as $\mathrm{pH}$ and temperature, are important factors for degradation of different types of fuel [7,8,10-13]. In aviation, where kerosene is a widely used type of fuel, biodamage leads to significant damage. Taking into account an annual growth of air transportation worldwide, this industry faces a serious costly challenge due to kerosene biodegradation [3,6,8]. Main features of kerosene contamination are the appearance of stable oil-water emulsions, acidification, and color and odor change [11].

The presence of water containing mineral salts is crucial for the development of biodamage $[14,15]$. In a dry fuel, microbial growth is not observed, but even a trace of water $(0.01-0.02 \%)$ is sufficient for harmful microorganisms to grow [16]. Under industrial conditions, a fuel always contains water $[15,16]$. During fuel biodegradation, several 
processes take place: development of a water layer on the bottom of the tank containing wastes and microorganisms (i); development of biofilm on the surface of tanks (ii); and clogging of pipelines and filter systems of aircrafts (iii) $[7,12,17]$. Altogether it leads to a metal corrosion in the zone of the water layer and subsequent destruction or delimitation of protective coatings [7,9]. Thus, biodamage changes fuel chemical composition, on the one hand, and, on the other hand, it causes impurities of biological origin (e.g., fragments of microbial biofilms) $[7,17,18]$.

Fuel biodamage is caused by bacteria, filamentous fungi, and yeast $[6,8,10,12,19]$. Filamentous micromycetes are the most dangerous among them because they form aggressive waste products and their mycelium can clog fuel systems $[8,14]$. The following fungal genera are common in biofuel: Aspergillus, Penicillium, Fusarium, Amorphotheca, Neosartorya, Paecilomyces, Talaromyces, Graphium, Cladosporium, Candida, Yarrowia, Schizosaccharomyces, Saccharomyces, and Pichia $[3,7,8,11,13,19-21]$. The main bacterial genera found in fuel are Bacillus, Flavobacterium, Sarcina, Micrococcus, Rhodococcus, Pseudomonas, Comamonas, Burkholderia, and Klebsiella [3,6,8,11,12,16,17,19-21]. The ability of microorganisms to biodegrade is due to their hydrolytic enzyme systems, and it is different depending on the substrates. The rate and severity of damage depends on fuel composition: linear hydrocarbons $>$ branched hydrocarbons $>$ aromatic hydrocarbons [10-12,20,22].

The majority of research on microbial biodegradation is focused on the pure cultures of bacterial or fungal strains isolated from the fuel $[3-8,18,20,21,23-26]$. However, in real systems, biodamage is caused by a complex impact of microbial communities [11,17,21,27-29]. Indeed, interactions of fungi and bacteria are common in a wide variety of habitats: decaying wood, human bodies, and water and soil environments [30]. Fuel-degrading micromycetes also exist in the form of the associations with bacteria. In this case, fuel degradation may be a synergetic process of microorganisms [5,6,31,32]. Most data on the coexistence of fungi and bacteria were obtained for soil systems. There bacteria interact with micromycetes forming close contact between each other [31,33]. On the one hand, bacteria provide fungal mycelium with more efficient settlement and substrate utilization [8,31]. They are related to a specific group of prokaryotes, hydrocarbon-oxidizing, or oleophilic bacteria, i.e., the bacteria that naturally utilize oils as their source of nutrients [8]. On the other hand, bacteria colonize a zone called the hyphosphere, which is formed around the fungal mycelium [32]. The hyphosphere is characterized by specific hydrostatic forces and the gradient of nutrients due to fungal exometabolites. In some cases, it was shown that the coexistence with fungal mycelium is necessary for biodegradation of hydrocarbons by the bacteria [34]. Fungi mediated attachment of nutrients particles (hydrocarbons) and bacteria to the network of the mycelium [32]. Fungi are responsible for transportation of nutrients [35-37] and bacterial cells $[31,32,34]$ through the nexus of hyphae and provide a specific microenvironment for prokaryotes [32]. There are two types for the transport of organics and bacterial cells: "fungal highways", through a thin layer of liquid environment with specific physicochemical parameters surrounding fungal hyphae, and "fungal pipelines", or translocation inside hyphae [32,35-37]. "Fungal highways" promote the direct motility of bacteria in water-unsaturated environments, whereas "fungal pipelines" supply hydrocarbons to bacteria [32,35-37]. Furuno et al. [35] showed the possibility of using the mycelium of micromycetes for isolation of oil-degrading bacteria Xanthomonas, Rhodococcus, and Pseudomonas from the contaminated environment. Generally, co-interactions between fungi and bacteria enhance the bioremoval of organic pollutants [37]. In addition, a large number of exohydrolases secreted by micromycetes increase the bioavailability of hydrophobic organic pollutants in the environment and contribute to the effective biodegradation of hydrocarbons by bacteria $[12,22,38,39]$.

So far, the data on the role of complex fungal and bacterial communities (but not their separate components) in fuel biodamage are scarce. Information about it may be essential for developing new strategies to prevent biodegradation. At the same time, the microbial communities from fuels may be considered as prospective agents for biodegradation of oil and fuel pollution. Application of the micromycete-bacterial communities during 
bioremediation of soils and waters contaminated with hydrophobic organic toxins is a promising area of research.

For the first time, to our knowledge, this study describes the community of micromycetes and uncultivated bacteria from the contaminated aviation kerosene (TS-1 jet fuel).

\section{Materials and Methods}

\subsection{Sampling and Cultures Isolation}

Micromycetes were isolated from two types TS-1 jet fuel samples of an aviation kerosene made according to the Russian standard (GOST 10227-86). One type was represented by colorless liquid; it had no features of contamination ( $\mathrm{pH}$ 7.5). Another type exhibited signs of contamination, e.g., of microscopic flakes; they were also represented by colorless liquids ( $\mathrm{pH}$ 7.5). Since fungi were isolated only from the samples with visible signs of contamination, the first type was considered as non-contaminated fuel. The samples were taken from the drain of jet fuel into steel barrels stored in a fuel and lubricants storage for 1.5 months. One sample was represented by colorless liquid; it had no features of contamination ( $\mathrm{pH} 7.5)$.

Each sample of the TS-1 jet fuel was taken in 3 replicates represented by $250 \mu \mathrm{L}$ of the fuel and was plated onto Petri dishes filled with selective organic media, for micromycetes isolation: the standard wort-agar medium (WA) [40] and Czapek medium (CM) [41]. After 3-10 days of incubation $\left(23^{\circ} \mathrm{C}\right)$, fungal colonies were transferred to a fresh medium, to obtain monosporal cultures, and incubated for 5 days. Monosporal fungal cultures were used for morphological identification and detection of growth capacity, with the presence of model mixture of hydrocarbons containing $n$-pentadecane, $n$-hexadecane, $n$-octadecane, and 1,2,4-trimethylbenzene ( $1.96 \% v / v$ of each compound).

In order to indicate the presence of cultured bacteria associated with the mycelium of the monospore fungal cultures, the following media were used: Rich medium [42] and Evans medium (EM) [43]. Previously, it was shown that EM and Rich medium are optimal for isolation of cultured heterotrophic bacteria from samples of contaminated oil and fuel [44-46]. All isolates of micromycetes were transferred either on liquid or solid media containing $2.0 \%(\mathrm{wt} / \mathrm{v})$ agar. They were incubated for 10 days, at $26^{\circ} \mathrm{C}$.

\subsection{Morphological Features of Micromycetes}

Isolated micromycete cultures were subjected to microscopic analysis for their identification. The analysis of the micromycetes morphology was performed on the 7-day-old cultures grown on the $\mathrm{CM}$ with $2 \%(\mathrm{wt} / \mathrm{v})$ yeast extract at $25^{\circ} \mathrm{C}$. Mycelium morphology was examined by light microscopy, on a microscope Leica DM 2500 (Leica Microsystems, Wetzlar, Germany) equipped with a DFC 7000T camera (Leica Microsystems, Wetzlar, Germany). Morphological features of fungal mycelium were evaluated by scanning electron microscopy (SEM). The samples were fixed with $2 \%(v / v)$ glutaraldehyde and dehydrated through graded ethanol series (including $100 \%$ ethanol) [47]. Then, they were transferred into absolute acetone, dried at the $\mathrm{CO}_{2}$ critical point on a Dryer HCP-2 (Hitachi, Tokyo, Japan), sputtered with gold and palladium in an IB-3 Ion Coater (Eico, Hitachinaka, Japan) [47], and examined under a scanning electron microscope JSM-6380LA (JEOL, Akishima, Japan).

The identification of the isolated micromycetes was done as per the guidelines [48-55] and general principles of fungal classification.

\subsection{Growth Ability on the TS-1 Jet Fuel}

Spore suspensions (volume of $0.3 \mathrm{~mL}$; optical density at $540 \mathrm{~nm}$ was of 0.2 ) of the micromycetes were transferred into the $20 \mathrm{~mL}$ glass tubes containing $3 \mathrm{~mL}$ of the sterile TS-1 jet fuel and the EM medium. The tubes were incubated in a thermostat, at $+28^{\circ} \mathrm{C}$, with shaking and monitored every 5 days for a month. The TS- 1 jet fuel was sterilized by filtration through the $50 \mathrm{~mm}$ round nitrocellulose membrane filters with a pore diameter 
of $0.24 \mu \mathrm{m}$ (Filter Solution, Moscow, Russia). Growth ability was scored visually by formation of mycelium flakes as: 0 points—no growth; 1 point - the appearance of medium turbidity, very small flakes; 2 points-flakes of medium size, easily distinguishable visually; 3 points-large flakes; 4 points—small clots; and 5 points—large mucus clots [56].

\subsection{Express Assay for the Detection of $16 S / 18 S$ rRNA Genes}

To verify the presence of bacteria in the fungal cultures, an express method of $16 \mathrm{~S} / 18 \mathrm{~S}$ rRNA detection was used. The genes of eukaryotic and prokaryotic small subunit rRNA were amplified by using the pair of universal primers (U515F: GTGYCAGCMGCCGCGGTAA and U1390R: TTGYACACACCGCCCGTC, designed in the study of Wang et al. [57]). The method is based on using primer pairs to highly conservative motives of small subunit rRNA. It is possible due to orthology between 16S rRNA and 18S rRNA genes [58]. With their help, it was possible to obtain amplicons of both prokaryotic and eukaryotic genes with the expected lengths of 900 and $1250 \mathrm{bp}$, respectively, for simultaneous expressdetection of fungal and bacterial genes.

Genomic DNA was extracted from $100 \mathrm{mg}$ of the mycelium with DNEasy PowerSoil Kit (Qiagen, Hilden, Germany) under sterile conditions. DNA was amplified on a Mastercycler Gradient DNA amplifier (Eppendorf, Hamburg, Germany), as described by Wang et al. [57].

\subsection{Next-Generation $16 S$ rRNA Amplicon Sequencing (16S rRNA Metabarcoding) and Bioinformatic Analysis}

Genomic DNA extraction was performed from the $2 \mathrm{~mL}$ biomass samples of each micromycete, with a PowerSoil DNA Isolation Kit (MO BIO Laboratories, Inc., Carlsbad, CA, USA), according to the manufacturer's protocol. The sequence corresponded to the hypervariable loop V4 of the 16S rRNA gene was amplified by polymerase chain reaction (PCR), using the primers pair F515: GTGCCAGCMGCCGCGGTAA and R806: GGACTACVSGGGTATCTAAT [59], fused with Illumina adapters, a pad, and a linker of two bases, along with barcodes. PCR amplification and sequencing libraries preparation were performed as described previously [60]. The libraries were sequenced on a MiSeq benchtop sequencer (Illumina, San Diego, USA), using a MiSeq 500 cycles kit (Illumina, San Diego, CA, USA) for $2 \times 250$ bp paired-ends sequencing.

Pretreatment of the datasets was done in QIIME v 1.9.1 [61]. To analyze next-generation $16 \mathrm{~S}$ rRNA amplicon sequencing (16S rRNA metabarcoding) data, direct and reverse sequences were combined. The dataset was cleaned from adapter sequences, chimeric sequences, and sequences of unsatisfactory quality. Sequences less than $200 \mathrm{nt}$ long and higher than $1000 \mathrm{nt}$ long were removed. Homologs of mitochondrial sequences were searched by BLAST [62] in the NCBI GenBank. The analysis and data visualization were performed in VAMPS [63], using the reference 16S rRNA database Silva release 138 v. 1.9.5/1.4.3 [64]. Venn diagrams were generated by using an online tool (http://bioinformatics.psb.ugent.be/webtools/Venn/).

\section{Results}

\subsection{Micromycetes Isolated from the TS-1 Jet Fuel}

A total of six monospore micromycete cultures were isolated from the samples, with visible signs of contamination (Tables 1 and 2). No fungal isolates were obtained from the sample without visual presence of contamination. Since fungi were isolated only from the samples with visible signs of contamination, the first type was considered as non-contaminated fuel. 
Table 1. Cultural and morphological characteristic of isolated micromycetes.

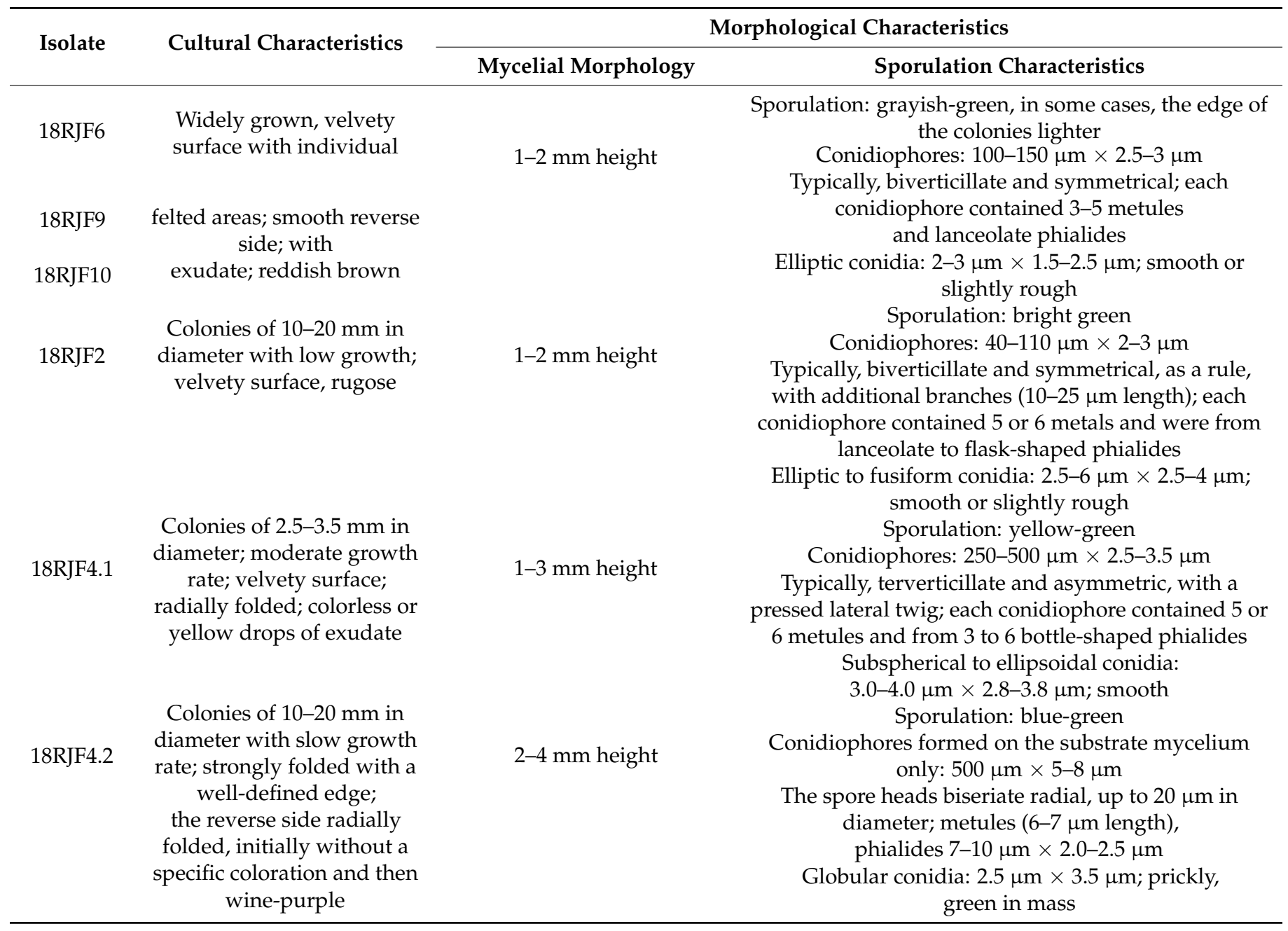

Table 2. Characteristics of micromycetes isolated from the TS- 1 jet fuel: sample isolation medium, micromycete species based on microscopic observation. degradation score of the TS-1 jet fuel scored as: 0 points—no growth; 1 point—cloudy solution, very small flakes; 2 points—flakes of medium size, easily distinguishable visually; 3 points—large flakes; 4 points—small clots; and 5 points-large clots. Mycelium lysis in the culture and visual presence of bacteria in the mycelium. EM-Evans medium, $\mathrm{CP}$-Czapek medium, and WA—worth agar.

\begin{tabular}{ccccc}
\hline Isolate & Isolation Medium & Micromycete & TS-1 Degradation Score & Mycelium Lysis \\
\hline 18RJF2 & EM & Talaromyces rugulosus & 0 & - \\
18RJF4.1 & CP & Penicillium chrysogenum & 3 & + \\
18RJF4.2 & CP & Aspergillus sydowii & 5 & + \\
18RJF6 & WA & Talaromyces amestolkiae & 5 & + \\
18RJF9 & WA & Talaromyces amestolkiae & 3 & + \\
18RJF10 & WA & Talaromyces amestolkiae & 2 & + \\
\hline
\end{tabular}

Fungal cultures were different in terms of colony type (Figure 1A-D) and sporulation morphology (Figure 1E-H). The cultures were different in terms of colony shape, color, sporulation, size, and morphology of conidia and conidiophores. The features of the obtained micromycete cultures are summarized in Table 1. 

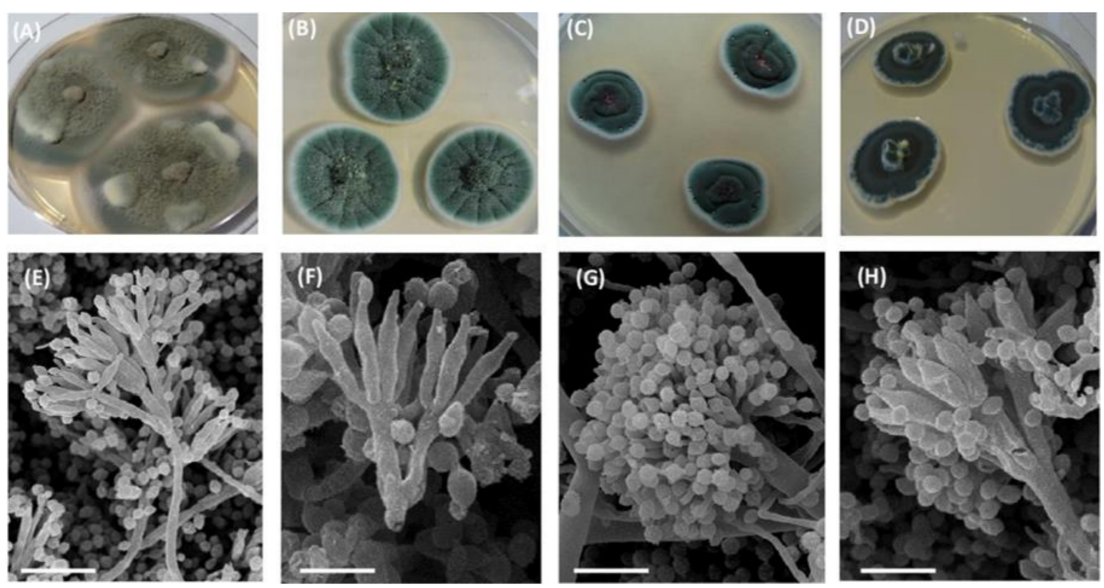

Figure 1. (A-D) Micromycete colonies on the solid culturing medium, seven days old. (E-H) Scanning electron images of micromycetes mycelium isolated from the TS- 1 jet fuel. (A,E) Talaromyces amestolkiae, (B,F) Penicillium chrysogenum, (C, G) Aspergillus sydowii, and (D,H) Talaromyces rugulosus. Scale bar: (F) $5 \mu \mathrm{m},(\mathbf{E}, \mathbf{G}) 10 \mu \mathrm{m}$, and (H) $20 \mu \mathrm{m}$.

Collectively, based on morphological analysis and fungal colonies characteristics, the obtained micromycetes belonged to the Eurotiales ascomycetes: Talaromyces amestolkiae (Figure 1A,E), Penicillium chrysogenum (Figure 1B,F), Aspergillus sydowii (Figure 1C,G), and T. rugulosus (Figure 1D,H). At the initial stages of cultivation, fungal colonies were recognized as geometrically correct, without visible signs of damage (Figure 2A). At the same time, after storage of the micromycetes isolates for 30 days on Petri dishes, lysis of the micromycetes mycelium occurred (Table 2 and Figure 2B).
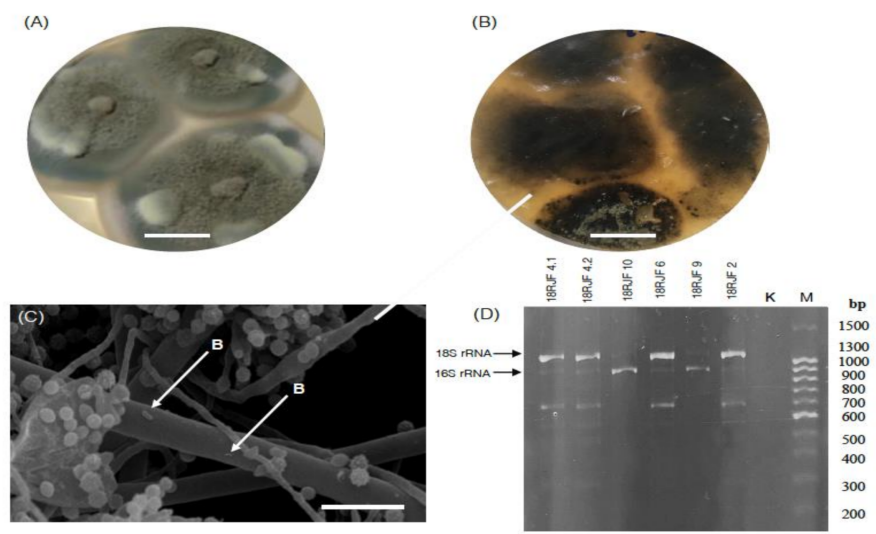

Figure 2. Analysis of the bacterial component of the communities isolated from the TS-1 jet fuel. (A) Native cultures of the micromycetes. Scale bar: $10 \mathrm{~mm}$. (B) Mycelium lysis. Scale bar: $10 \mathrm{~mm}$. (C) Bacteria attachment to the fungal hyphae in the isolate 18RJF9. Scale bar: $10 \mu \mathrm{m}$, arrows indicate the bacterial cells-B. (D) Separation of the PCR products obtained by using the primers for 16S rRNA detection in agarose gel. $\mathrm{K}$ is the negative control; $\mathrm{M}$ is the $100+\mathrm{bp}$ DNA ladder.

No single approach resulted in the growth of the cultured bacteria in all the fungal monospore isolates (data not shown). Although bacterial growth was detected neither at the stage of fungi isolation nor after mycelium lysis, SEM evidence revealed single bacterial cells associated with fungal hyphae (Figure 2C).

\subsection{Bacterial Component of the Micromycetes' Biomass Isolated from Jet Fuel Communities Revealed by $16 S$ rRNA Data}

The 16S/18S rRNA PCR analysis of the biomass of micromycetes revealed the presence of two amplicons (Figure 2D) with the length of $1250 \mathrm{bp}$ (in 18RJF6, 18RJF4.2, and 18RJF2) 
and $900 \mathrm{bp}$ (18RJF4.1, 18RJF4.2, 18RJF6, 18RJF9, and 18RJF10). The $900 \mathrm{bp}$ fragment corresponded to bacterial 16S rRNA gene, whereas the $1250 \mathrm{bp}$ fragment corresponded to eukaryotic $18 \mathrm{~S}$ rRNA (obtained due to non-specific annealing of the primers with eukaryotic 18S rRNA). No 900 bp product was observed in the 18RJF2. Thus, the biomass of five of the six isolates of micromycetes isolated from the TS- 1 jet fuel contained both bacteria and micromycetes and represented micromycete-bacterial communities. The presence of bacteria was also confirmed by SEM observations (Figure 2C). Single bacterial cells were observed on the mycelium in some cases.

Most of the reads in the $16 \mathrm{~S}$ rRNA metabarcoding datasets were represented by fungal mitochondrial 16S rRNA due to its orthology with bacterial 16S rRNA [58]. Based on our homologs search in the NCBI GenBank database, the highest homology of mitochondrial reads was observed with that of genera Talaromyces, Penicillium, and Aspergillus (98-100\%, 99-100\% coverage, Table 3). The sequences were deposited into NCBI GenBank, under the accession numbers listed in Table 3. Thus, the putative taxonomical affiliation with micromycetes obtained based on microscopic observations was confirmed by the 16S rRNA metabarcoding analysis. The number of bacterial genera in the isolates was in the range of 39-110. The percentage of unidentified reads after removing fungal sequences from consideration did not exceed 9\%. The 16S rRNA-based metabarcoding study of the jet fuel community of micromycetes containing bacteria (18RJF4.1, 18RJF4.2, 18RJF6, 18RJF9, and 18RJF10) showed the absence of Archaea and presence of four predominant bacterial phyla, Proteobacteria, Actinobacteria, Firmicutes, and Bacteroidetes (Figure 3A). The vast majority of bacteria in all isolates was related to Gram-negative clades. The Isolate 18RJF4.2 had the highest prevalence of the phylum Bacteroidetes (0.4\%). Actinobacteria were predominant in 18RJF9 and 18RJF10, with a relative abundance of $92 \%$ and $76 \%$, respectively. In 18RJF4.1, the phylum Proteobacteria was present with a relative abundance of $99 \%$. In three isolates (18RJF4.1, 18RJF4.2, 18RJF4.6), relatively high fraction of bacterial reads corresponded to Bacteroidetes were also detected (Figure 3A).

Table 3. Microorganisms in the samples of the TS-1 fuel based on rRNA sequencing data: fungal genera based on mitochondrial DNA sequence, as well as their NCBI GenBank IDs and bacteria with putative oil degradation activity.

\begin{tabular}{|c|c|c|c|}
\hline Isolate & Mitochondrial rRNA & GenBank ID & Bacteria with Putative Petroleum Destruction Activity \\
\hline 18RJF2 & Talaromyces & MW393516 & None \\
\hline 18RJF4.1 & Penicillium & MW393517 & $\begin{array}{c}\text { Sphingomonas, Bacillus, Rhodococcus, Halomonas, } \\
\text { Nocardioides }\end{array}$ \\
\hline 18RJF4.2 & Aspergillus & MW393518 & $\begin{array}{c}\text { Sphingomonas, Bacillus, Pseudomonas, Stenotrophomonas, } \\
\text { Arthrobacter, Halomonas, Nocardioides }\end{array}$ \\
\hline 18RJF6 & Talaromyces & MW393519 & $\begin{array}{c}\text { Sphingomonas, Bacillus, Pseudomonas, Stenotrophomonas, } \\
\text { Arthrobacter, Halomonas, Nocardioides }\end{array}$ \\
\hline 18RJF9 & Talaromyces & MW393520 & $\begin{array}{c}\text { Sphingomonas, Bacillus, Pseudomonas, Stenotrophomonas, } \\
\text { Arthrobacter, Streptomyces, Nocardioides }\end{array}$ \\
\hline 18RJF10 & Talaromyces & MW393521 & $\begin{array}{c}\text { Sphingomonas, Bacillus, Arthrobacter, Halomonas, } \\
\text { Streptomyces, Nocardioides }\end{array}$ \\
\hline
\end{tabular}

The communities studied contained four common bacterial genera: Sphingomonas, Chthoniobacter, Bacillus, Nocardioides (Figure 3). In 18RJF9 and 18RJF10, most of the reads corresponded to Streptomyces, 56\% and 69\%, respectively (Figure 3C); other Actinobacteria genera were not abundant. Despite the relatively high total number of Bacteroidetes, there were no prevalent genera related to this phylum (Figure 3C). In the 18RJF9, Bacillus $(33 \%)$ was predominant. In the isolates 18RJF4.1, 18RJF4.2, and 18RJF6, the Proteobacteria Shewanella (6-18\%), Sphingomonas (3-6\%), and Halomonas (14-25\%) were relatively abundant (Figure 3C). 

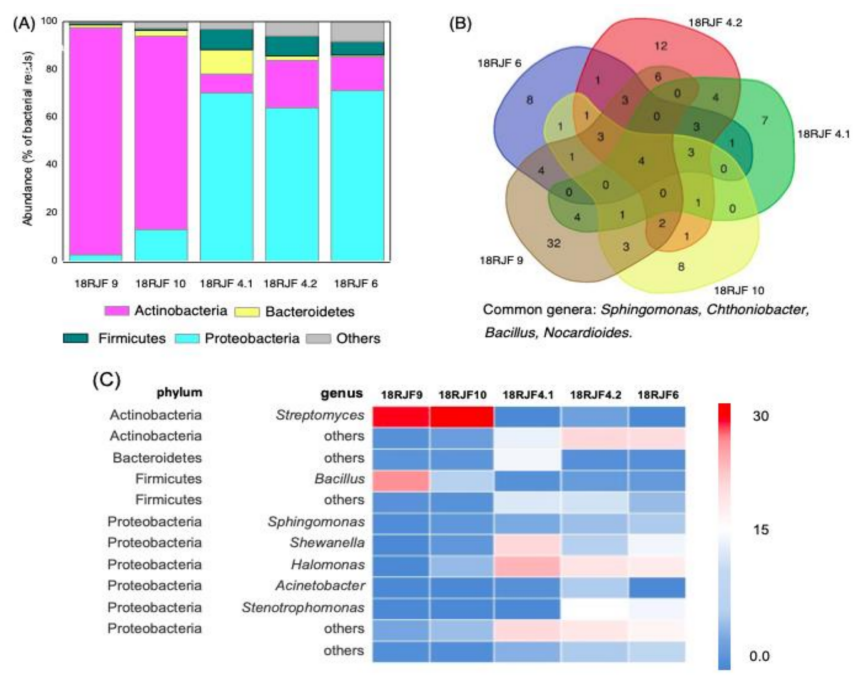

Figure 3. (A) Abundance of bacterial phyla in the communities isolated from the TS-1 jet fuel based on the sequencing of $16 \mathrm{~S}$ rRNA libraries. The percentage of bacterial NGS reads corresponding to each phylum (of total prokaryotic reads) is shown. "Others" are unidentified sequences. (B) The number of common genera in the communities isolated from the TS-1 jet fuel based on 16S rRNA metabarcoding data analysis. (C) Frequency heatmap based on 16S rRNA sequencing. The color corresponds to the fraction of NGS reads in each isolate.

\subsection{The Growth Capacity of Isolated Communities on the TS-1 Jet Fuel}

The growth capacity of the micromycete isolates on TS-1 fuel was assessed. The scores assigned to the isolates depended on the growth degree and varied from the absence of growth to the formation of large gray or light clots in the medium phase or on the phases' boundary.

Communities derived from TS- 1 jet fuel can be divided into 3 groups depending on their ability to decompose this fuel: (1) active destructors (five points), (2) potentially active destructors (four points), and (3) inactive or random (three or less points). The first group includes 2 isolates (18RJF4.2 and 18RJF6), the second-3 (18RJF4.1, 18RJF9 and 18RJF10), and the third-1 (18RJF1) (Table 2).

\section{Discussion}

Numerous studies in the last two decades have demonstrated that a wide variety of bacteria and fungi, including molds and yeasts, may colonize fuels such as diesel, biodiesel, and kerosene $[7,8,11,15,65-68]$. In addition, many of these microbes may actually degrade oil contaminations $[3-5,11]$.

In five of the six isolates of micromycetes, we detected amplicones of bacterial $16 \mathrm{~S}$ rRNA. Bacteria-containing isolates were passed through a pipeline of analysis of metabarcoding based on 16S rRNA gene. Since the mitochondrial gene of the ribosome small subunit RNA is an ortholog of the bacterial 16S rRNA gene, these genes are characterized by a relatively high degree of homology. Therefore, 16S rRNA libraries often contain mitochondrial reads [58]. In the isolates studied, a significant fraction of bacterial reads was represented by fungal sequences. Based on the homologs search, results of metabarcoding analysis revealed the presence of Talaromyces, Penicillium, and Aspergillus in the isolates. Although high homology of the mitochondrial ribosomal small subunit RNA gene is not solid evidence for precise micromycete identification, it is a confirmation of microscopic data and visual observations. Thus, three genera of micromycetes were isolated from the TS-1 jet fuel. Indeed, they are abundant in petroleum-contaminated soil and show kerosenedegrading activity $[7,8,11,20,24,25,69]$. Penicillium and Aspergillus are considered to be the most effective utilizers of hydrocarbons (particularly kerosene fuel) among fungi [24,25], but Aspergillus demonstrates a higher growth rate [24]. It should be noted that the same 
fungi were isolated from oil samples in different geographical regions and under different experimental conditions [2-6,8]. In this regard, they may be considered as widespread fungal components of such kerosene microbial communities.

In the isolates where $16 \mathrm{~S}$ rRNA amplicons were detected, hyphae lysis of the micromycetes was observed after 30 days of cultivation. In fact, lysis of fungal mycelium is associated with the presence of vigorously dividing bacteria [70]. Moreover, single bacterial cells were observed on the surface of hyphae of some isolates. In our previous works, thirteen bacterial strains were isolated from the contaminated TS- 1 aviation kerosene by conventional microbiological methods on the Rich medium. Their taxonomic affiliation was verified by $16 \mathrm{~S}$ rRNA sequencing $[45,46]$. Kerosene was characterized by a diverse bacterial composition that included the following genera: Sphingobacterium, Alcaligenes, Rhodococcus, and Deinococcus. Isolated strains were capable of the degradation of hydrocarbons and production of biosurfactants $[45,46]$. At the same time, in this study, the same bacterial genera were indicated in monospore fungal cultures based on 16S rRNA metabarcoding. However, it was impossible to isolate bacteria from these communities from the TS- 1 jet fuel grown on the Rich medium, WA, CM, and the EM after five days of incubation (see Materials and Methods). It might indicate a close relationship between fungi and bacteria.

Prokaryotes are known as effective hydrocarbon-utilizing microorganisms [12,19]. The most common fuel=degrading bacteria are related to Firmicutes, Bacteroidetes, Actinobacteria, and Proteobacteria $[13,17,29]$. A total of $16 \mathrm{~S}$ rRNA metabarcoding data revealed the presence of these main phyla of oil-degrading bacteria in all the samples of TS-1 jet fuel. They were detected previously and isolated from oil-contaminated soils and samples of petroleum [12,39]. In addition, effective oil degradation has been reported for some archaea, e.g., Euryarchaeota, Thaumarchaeota, and Crenarchaeota. Oil-contaminated soils and ponds are characterized by very complex archaeal communities, and their taxonomic structure is more complex than that of bacteria [71,72]. Especially, halophilic archaea are abundant in habitats with high salinity [73]. At the same time, no significant number of archaea was detected in the studied TS- 1 jet fuel sample.

Many bacterial genera with the ability to degrade hydrocarbons were isolated from soil or water bodies contaminated by oil. Mycobacterium, Arthrobacter, Marinobacter, Achromobacter, Alcaligenes, Corynebacterium, Flavobacterium, Micrococcus, Nocardia, Pseudomonas, Bacillus, Dietzia, Gordonia, Halomonas, Cellulomonas, Rhodococcus, and Alcanivorax are especially common petroleum degraders $[8,13,17,26,74]$. All studied communities contained bacterial genera with the reported ability to perform petroleum degradation (Table 3); thus, they might be involved into kerosene biodamage as well, e.g., Sphingomonas, Bacillus, Rhodococcus, Nocardioides, Halomonas, Pseudomonas, Stenotrophomonas, Arthrobacter, and Streptomyces. The Actinobacteria Streptomyces was predominant in two TS-1 samples. It is able to degrade linear hydrocarbon and polycyclic aromatic hydrocarbons, as well as hydroxyalkanoates $[8,12,17,26,39,75]$. In three isolates, a relatively high amount of Halomonas, Shewanella, Stenotrophomonas, and Acinetobacter was observed, and, in one isolate, Bacillus was predominant. Petroleum degradation is well-known for Shewanella, Stenotrophomonas, and Acinetobacter $[12,19,67,76]$. Growth and degradation of hydrocarbons by Halomonas have been described under hypersaline conditions and in marine environments $[74,77]$. Some of these bacteria show biosurfactant-producing activity, which is important for effective utilization of hydrophobic substrates [12,76]. Notably, Bacillus, Nocardioides, and Sphingomonas were observed in all isolates studied.

All studied isolates, namely 18RJF6, 18RJF4.2, 18RJF9, 18RJF10, and 18RJF4.1-where the first two belonged to the group of active hydrocarbon degraders and the remaining potentially active destructors-contained bacterial component in their hyphosphere. Based on our results, there was no correlation between micromycete genus and TS- 1 jet fuel biodegradation. Since these isolates exhibited different bacterial composition, it raises the question of whether qualitative and quantitative characteristics of bacterial components of such communities determine effectiveness of fuel degradation. This sparks a scientific quest to reveal the numerical criteria of "successful" fuel-degrading community. For this 
purpose, it will be necessary to collect a high number of new data of such communities isolated from fuel, to subject them to statistical analysis of generated metabarcoding data. Nevertheless, we took an attempt to find some common patterns of active fuel-degrading communities based on our primary data. First, active fuel-degrading communities were characterized by high total diversity of Actinobacteria, whereas potentially active (with an exception of 18RJF4.1) were characterized only by a high abundance of Streptomyces and low number of others (Figure 3C). Second, active and potentially active communities contained high numbers of reads of either Bacillus or Halomonas and Stenotrophomonas, which are fuel-degrading bacteria (Figure 3C). In general, active and potentially active communities contained a higher number of abundant bacterial genera with reported fuel degradation. When growing in fuel, hydrocarbon-oxidizing bacteria form communities that make up a single chain of hydrocarbon oxidation $[8,17]$. Each microorganism in such a community uses predominantly certain groups of hydrocarbons along specific metabolic pathways. When communities of microorganisms are exposed together, both a larger amount and a wider range of hydrocarbons are extracted from oil and petroleum products. One can speculate that abundance of more than one (and better several) genera of fueldestructing bacteria is important for "successful" fuel degradation by a community. It can be explained by higher diversity of genus-specific enzymes degrading potentially higher numbers of hydrocarbons.

The existence of petroleum-degrading microorganisms in the community raises the question of their synergism in substrate utilization and biodamage of the fuel. The presence of uncultivated forms of bacteria might indicate their very close interactions with fungi. Formation of a stable community between bacteria and fungal mycelium is a strategy for their coexistence $[28,33,78,79]$. Synergism of bacteria and fungi in substrate utilization is a well-known phenomenon. Bacteria exhibit a diverse enzymatic system for catabolism of aromatic and aliphatic, saturated and desaturated, and branched and unbranched hydrocarbons $[7,8,12,80]$. They use a broad range of oxygenases to insert oxygen atoms to organic molecules $[8,81]$. The fungal genome also encodes diverse enzymes that transform a wide range of hydrocarbons, which are expressed to utilize such substrates $[8,12,27,82]$. In contrast to bacteria, most fungi express extracellular oxidoreductases acting beyond the zone of microorganisms' growth $[32,83]$. It makes it possible to oxidize extremely hydrophobic substrates to their more hydrophilic derivatives, which may diffuse to fungi and bacteria [83]. Thus, the communities of fungi and bacteria implement co-metabolism of fuel: It was shown that these components cannot degrade some hydrocarbons separately [83]. Fungi provide a microenvironment favorable for bacteria in their hyphosphere. It is essential for the establishment constant metabolic crosstalk, as well as immobilization of motile bacteria walking in the environment [32]. In our work, the presence of bacteria on the mycelium is indirect evidence of such interactions. The network of mycelium serves as a "transport vector" for dispersal movement of bacteria by "fungal highways" and for transport of hydrocarbons and metabolites by "fungal pipeline" to bacterial cells [28,31,32,34-36,83]. Moreover, some fungi form endosymbiosis with bacteria; therefore, they may also be transferred by the "pipeline" [33,78]. Communities of hydrocarbon-degrading fungi and bacteria form biofilms $[17,18,28,83,84]$. Genes for biofilm formation were detected in the fungal-interactive bacterium Burkholderia terrae BS001 [80]. Hydrocarbon-degrading bacteria live in a hydrophilic environment. At the same time, their immobilization in the vicinity of a substrate is essential for degradation $[28,46,83]$. Thus, biofilm formation is important for microorganisms anchoring on a hydrophobic surface [83]. Extracellular polymeric substances are an important mandatory part of all biofilms [85]. They form a network of extracellular matrixes that accumulates hydrocarbons and exhibits sites of hydrophobicsubstance binding [83]. Thus, biofilm formation increases hydrocarbon availability to microorganisms. Moreover, biofilm formation increases stability of the microbial community under adverse conditions $[84,85]$. Additionally, microorganisms may be involved in the formation of multispecies biofilms, providing stability for formed communities [85]. 
Numerous recent studies $[84,86,87]$ have shown a promising trend in the applications of the fungal-bacterial biofilm in diverse fields.

Collectively, according to the literature sources, communities between hydrocarbondegrading fungi and bacteria seem to be a form of microbial associations. They have greater degradable potential than pure cultures. In the current research, we, at the first time, isolated micromycete cultures from the TS- 1 jet fuel. The fruits of the work already include a confirmation of an importance of community formation for better hydrocarbon utilization and high degree of interaction between oil-degrading fungi and high degree of interaction between fungi and bacteria in such communities. The inability to isolate bacteria associated with fungal mycelium and fuel degradation only by bacteria containing mycelium gives the task ahead to evaluate the presence of bacteria in fungal isolates from different types of fungi. It may be important for development of new strategies for prevention of fuel biodamage and hydrocarbon pollutants' biodeterioration.

\section{Conclusions}

Micromycetes and bacteria are called biodegraders of fuel, including TC-1 jet fuel. In this paper, we studied the $16 \mathrm{~S}$ rRNA metabarcoding of the biomass of micromycetes isolated from TS-1 jet fuel and showed that they are mainly micromycete bacterial communities with non-cultured bacterial forms. The high efficiency of hydrocarbon-oxidizing bacteria and fungi in the destruction of hydrocarbons is widely known. However, according to our data, only isolates of micromycetes that are communities with bacteria are effective in terms of degradation of TS-1 jet fuel, whereas the isolate of a micromycete devoid of bacteria is not capable of growth on fuels. These data are valuable for developing new strategies for protecting fuels from biodegradation and creating new approaches to waste biodegradation.

Author Contributions: Conceptualization, E.L.; methodology, E.L., G.D., and T.S.; validation, E.I., formal analysis, K.C., A.A., and E.L.; resources, G.D. and E.L.; data curation, T.S.; writing-original draft preparation, K.C.; writing-review and editing, K.C., T.S., A.A. and E.L.; visualization, A.A. and K.C.; supervision, E.L.; project administration, E.L. All authors have read and agreed to the published version of the manuscript.

Funding: The authors thank National University of Oil and Gas «Gubkin University. This work was supported by Russian Foundation for Basic Research, project no. 18-29-05067.

Institutional Review Board Statement: Not applicable.

Informed Consent Statement: Not applicable.

Data Availability Statement: The data presented in this study are openly available in GenBank at reference numbers: MW393516, MW393517, MW393518, MW393519, MW393520, MW393521.

Conflicts of Interest: The authors declare no conflict of interest. The funders had no role in the design of the study; in the collection, analyses, or interpretation of data; in the writing of the manuscript; or in the decision to publish the results.

\section{References}

1. Iverson, W.P. Microbial corrosion of metals. In Advances in Applied Microbiology; Academic Press: Cambridge, MA, USA, 1987; Volume 32, pp. 1-36.

2. Gerasimenko, A.A.; Yampol'skaya, T.E. Exfoliation corrosion of aluminum alloys II. Protection methods, their effectiveness and improvement. Prot. Met. 2000, 36, 397-407. [CrossRef]

3. Itah, A.Y.; Brooks, A.A.; Ogar, B.O.; Okure, A.B. Biodegradation of international jet A-1 aviation fuel by microorganisms isolated from aircraft tank and joint hydrant storage systems. Bull. Environ. Contam. Toxicol. 2009, 83, 318-327. [CrossRef]

4. Buddie, A.G.; Bridge, P.D.; Kelley, J.; Ryan, M.J. Candida keroseneae sp. nov., a novel contaminant of aviation kerosene. Lett. Appl. Microbiol. 2011, 52, 70-75. [CrossRef] [PubMed]

5. Soriano, A.U.; Martins, L.F.; Ventura, E.S.D.; de Landa, F.H.G.T.; da Auraujo Valoni, E.; Faria, F.R.D.; Ferreira, R.F.; Clara, M.; Fallera, K.; Valério, R.R.; et al. Microbiological aspects of biodiesel and biodiesel/diesel blends biodeterioration. Int. Biodeterior. Biodegrad. 2015, 99, 102-114. [CrossRef] 
6. Passman, F.J. Microbial contamination and its control in fuels and fuel systems since 1980-A review. Int. Biodeterior. Biodegrad. 2013, 81, 88-104. [CrossRef]

7. Rodríguez-Rodríguez, C.E.; Rodríguez, E.; Blanco, R.; Cordero, I.; Segura, D. Fungal contamination of stored automobile-fuels in a tropical environment. J. Environ. Sci. 2010, 22, 1595-1601. [CrossRef]

8. Varjani, S.J. Microbial degradation of petroleum hydrocarbons. Bioresour. Technol. 2017, 223, 277-286. [CrossRef]

9. Koshlaf, E.; Ball, A. Soil bioremediation approaches for petroleum hydrocarbon polluted environments. Aims Microbiol. 2017, 3, 25-49. [CrossRef]

10. Leahy, J.G.; Colwell, R.R. Microbial degradation of hydrocarbons in the environment. Microbiol. Mol. Biol. Rev. 1990, 54, 305-315. [CrossRef]

11. Bücker, F.; de Moura, T.M.; da Cunha, M.E.; de Quadros, P.D.; Beker, S.A.; Cazarolli, J.C.; Caramão, E.B.; Frazzon, A.P.G.; Bento, F.M. Evaluation of the deteriogenic microbial community using qPCR, n-alkanes and FAMEs biodegradation in diesel, biodiesel and blends (B5, B10, and B50) during storage. Fuel 2018, 233, 911-917. [CrossRef]

12. Das, N.; Chandran, P. Microbial degradation of petroleum hydrocarbon contaminants: An overview. Biotechnol. Res. Int. 2011, 2011, 941810. [CrossRef] [PubMed]

13. Shabir, G.; Afzal, M.; Anwar, F.; Tahseen, R.; Khalid, Z.M. Biodegradation of kerosene in soil by a mixed bacterial culture under different nutrient conditions. Int. Biodeterior. Biodegrad. 2008, 61, 161-166. [CrossRef]

14. Boychenko, S.; Shkilnuk, I.; Turchak, V. The problems of biopollution with jet fuels and the way of achieving solution. Transport. 2008, 23, 253-257. [CrossRef]

15. Sørensen, G.; Pedersen, D.V.; Nørgaard, A.K.; Sørensen, K.B.; Nygaard, S.D. Microbial growth studies in biodiesel blends. Bioresour. Technol. 2011, 102, 5259-5264. [CrossRef] [PubMed]

16. Shkilniuk, I.; Boichenko, S. Methodically organizational principles of biological stability providing of aviation fuels. Pr. Inst. Lotnictwa 2014, 237, 76-83. [CrossRef]

17. Bücker, F.; Barbosa, C.S.; Quadros, P.D.; Bueno, M.K.; Fiori, P.; te Huang, C.; Frazzon, A.P.G.; Ferrão, M.F.; de Oliveira Camargo, F.A.; Bento, F.M. Fuel biodegradation and molecular characterization of microbial biofilms in stored diesel/biodiesel blend B10 and the effect of biocide. Int. Biodeterior. Biodegrad. 2014, 95, 346-355. [CrossRef]

18. Chiciudean, I.; Mereuţă, I.; Ionescu, R.; Vassu, T.; Tănase, A.M.; Stoica, I. Jet A-1 Bacterial contamination: A case study of cultivable bacteria diversity, alkane degradation and biofilm formation. Pol. J. Environ. Stud. 2019, 28, 4139-4146.

19. Atlas, R.M. Microbial degradation of petroleum hydrocarbons: An environmental perspective. Microbiol. Rev. 1981, 45, 180-209. [CrossRef]

20. Chaillan, F.; Le Flèche, A.; Bury, E.; Phantavong, Y.H.; Grimont, P.; Saliot, A.; Oudot, J. Identification and biodegradation potential of tropical aerobic hydrocarbon-degrading microorganisms. Res. Microbiol. 2004, 155, 587-595. [CrossRef]

21. De Azambuja, A.O.; Bücker, F.; de Quadros, P.D.; Zhalnina, K.; Dias, R.; Vacaro, B.B.; Bento, F.M. Microbial community composition in Brazilian stored diesel fuel of varying sulfur content, using high-throughput sequencing. Fuel 2017, 189, 340-349. [CrossRef]

22. Pereira, E.; Napp, A.P.; Allebrandt, S.; Barbosa, R.; Reuwsaat, J.; Lopes, W.; Maria do Carmo, R.P. Biodegradation of aliphatic and polycyclic aromatic hydrocarbons in seawater by autochthonous microorganisms. Int. Biodeterior. Biodegrad. 2019, 145, 104789. [CrossRef]

23. Hasan, I. Biodegradation of kerosene by Aspergillus niger and Rhizopus stolonifer. Appl. Environ. Microbiol. 2014, 2, 31-36.

24. Lotfinasabasl, S.; Gunale, V.R.; Rajurkar, N.S. Assessment of petroleum hydrocarbon degradation from soil and tarball by fungi. Biosci. Discov. 2012, 3, 186-192.

25. Dhar, K.; Dutta, S.; Anwar, M.N. Biodegradation of petroleum hydrocarbon by indigenous fungi isolated from ship breaking yards of Bangladesh. Int. Res. J. Biol. Sci. 2014, 3, 22-30.

26. Mnif, S.; Chamkha, M.; Sayadi, S. Isolation and characterization of Halomonas sp. strain C2SS100, a hydrocarbon-degrading bacterium under hypersaline conditions. J. Appl. Microbiol. 2009, 107, 785-794. [CrossRef]

27. Ameen, F.; Moslem, M.; Hadi, S.; Al-Sabri, A.E. Biodegradation of diesel fuelhydrocarbons by mangrove fungi from Red Sea Coast of Saudi Arabia. Saudi J. Biol. Sci. 2016, 23, 211-218.

28. Boonchan, S.; Britz, M.L.; Stanley, G.A. Degradation and mineralization of high-molecular-weight polycyclic aromatic hydrocarbons by defined fungal-bacterial cocultures. Appl. Environ. Microbiol. 2000, 66, 1007-1019. [CrossRef]

29. White, J.; Gilbert, J.; Hill, G.; Hill, E.; Huse, S.M.; Weightman, A.J.; Mahenthiralingam, E. Culture-independent analysis of bacterial fuel contamination provides insight into the level of concordance with the standard industry practice of aerobic cultivation. Appl. Environ. Microbiol. 2011, 77, 4527-4538. [CrossRef]

30. Boer, W.D.; Folman, L.B.; Summerbell, R.C.; Boddy, L. Living in a fungal world: Impact of fungi on soil bacterial niche development. FEMS Microbiol. Rev. 2005, 29, 795-811.

31. Furuno, S.; Päzolt, K.; Rabe, C.; Neu, T.R.; Harms, H.; Wick, L.Y. Fungal mycelia allow chemotactic dispersal of polycyclic aromatic hydrocarbon-degrading bacteria in water-unsaturated systems. Environ. Microbiol. 2010, 12, 1391-1398.

32. Wick, L.Y.; Furuno, S.; Harms, H. Fungi as transport vectors for contaminants and contaminant-degrading bacteria. In Handbook of Hydrocarbon and Lipid Microbiology; Springer: Berlin/Heidelberg, Germany, 2010; pp. 1555-1561.

33. Partida-Martinez, L.P.; Hertweck, C. Pathogenic fungus harbours endosymbiotic bacteria for toxin production. Nature 2005, 437, 884-888. [CrossRef] [PubMed] 
34. Wick, L.Y.; Remer, R.; Würz, B.; Reichenbach, J.; Braun, S.; Schäfer, F.; Harms, H. Effect of fungal hyphae on the access of bacteria to phenanthrene in soil. Environ. Sci. Technol. 2007, 41, 500-505. [CrossRef] [PubMed]

35. Furuno, S.; Remer, R.; Chatzinotas, A.; Harms, H.; Wick, L.Y. Use of mycelia as paths for the isolation of contaminant-degrading bacteria from soil. Microb. Biotechnol. 2012, 5, 142-148. [CrossRef] [PubMed]

36. Banitz, T.; Johst, K.; Wick, L.Y.; Schamfuß, S.; Harms, H.; Frank, K. Highways versus pipelines: Contributions of two fungal transport mechanisms to efficient bioremediation. Environ. Microbiol. Rep. 2013, 5, 211-218. [CrossRef]

37. Schamfuß, S.; Neu, T.R.; Harms, H.; van der Meer, J.R.; Tecon, R.; Wick, L.Y. Mycelial networks enhance the bioavailability of PAH in water unsaturated environments. Environ. Sci. Technol. 2013, 47, 6908-6915. [CrossRef]

38. Wick, L.; De Munain, A.; Springael, D.; Harms, H. Responses of mycobacterium sp. LB501T to the low bioavailability of solid anthracene. Appl. Microbiol. Biotechnol. 2002, 58, 378-385.

39. Ferradji, F.Z.; Mnif, S.; Badis, A.; Rebbani, S.; Fodil, D.; Eddouaouda, K.; Sayadi, S. Naphthalene and crude oil degradation by biosurfactant producing Streptomyces spp. isolated from Mitidja plain soil (North of Algeria). Int. Biodeterior. Biodegrad. 2014, 86, 300-308. [CrossRef]

40. Rapp, P.; Backhaus, S. Formation of extracellular lipases by filamentous fungi, yeasts, and bacteria. Enzym. Microb. Technol. 1992, 14, 938-943. [CrossRef]

41. Thom, C.; Church, M.B. The Aspergilli; Williams and Wilkins Co.: Baltimore, MD, USA, 1926; p. 272.

42. Matlakowska, R.; Sklodowska, A. The culturable bacteria isolated from organic-rich black shale potentially useful in biometallurgical procedures. J. Aapplied Microbiol. 2009, 107, 858-866. [CrossRef]

43. Evans, C.G.T.; Herbert, D.; Tempest, D.W. Chapter XIII the continuous cultivation of microorganisms: 2, construction of a chemostat. In Methods in Microbiology; Academic Press: Cambridge, MA, USA, 1970; Volume 2, pp. $277-327$.

44. Lobakova, E.; Vasilieva, S.; Kashcheeva, P.; Ivanova, E.; Dolnikova, G.; Chekanov, K.; Dedov, A. New bio-hybrid materials for bioremoval of crude oil spills from marine waters. Int. Biodeterior. Biodegrad. 2016, 108, 99-107. [CrossRef]

45. Shapiro, T.; Dolnikova, G.; Nemtseva, N.; Sanjieva, D.; Lobakova, E. Identification and physiological characterisationtics of athe consortium of hydrocarbon-oxidizing bacteria of oil and oilpetroleum products. J. Microbiol. Epidemiol. Immunobiol. 2018, 107-113. [CrossRef]

46. Ivanova, E.A.; Lobakova, E.S.; Idiatulov, R.K.; Shapiro, T.N.; Sandzhieva, D.A.; Kuznetsova, O.V.; Zaitseva, Y.u.N.; Dzhabrailova, K.h.S.; Dedov, A.G. Biocomposite materials for purification of aqueous media contaminated with hydrocarbons. Pet. Chem. 2019, 59, 420-426. [CrossRef]

47. Gorelova, O.A.; Kosevich, I.A.; Baulina, O.I.; Fedorenko, T.A.; Torshkhoeva, A.Z.; Lobakova, E.S. Associations between the White Sea invertebrates and oxygen-evolving phototrophic microorganisms. Mosc. Univ. Biol. Sci. Bull. 2009, 64, 16-22. [CrossRef]

48. Raper, K.B.; Fennel, D.I. The Genus Aspergillus; Williams \& Wilkins: Baltimore, MD, USA, 1965; p. 686.

49. Raper, K.B.; Thom, C.; Fennell, D.I. A Manual of the Penicillia; Hefner Publishing Co.: New York, NY, USA, 1949 ; p. 875.

50. Pitt, G.I. A Laboratory Guide to Common Penicillium Species, 2nd ed.; CSIRO Food Research Laboratory: North Ryde, NSW, Australia, 1968; p. 188.

51. Klich, M. Identification of Common Aspergillus Species; CBS: New York, NY, USA, 2002; p. 116.

52. Samson, R.A.; Frisvard, J.C. Penicillium subgenus Penicillium: New taxonomic schemes, mycotoxins and other extrolites. Stud. Mycol. 2004, 49, 251.

53. Yilmaz, N.; Houbraken, J.; Hoekstra, E.S.; Frisvad, J.C.; Visagie, C.M.; Samson, R.A. Delimitation and characterisation of Talaromyces purpurogenus and related species. Pers. Mol. Phylogeny Evol. Fungi 2012, 29, 39-54. [CrossRef] [PubMed]

54. Yilmaz, N.; Visagie, C.M.; Houbraken, J.; Frisvad, J.C.; Samson, R.A. Polyphasic taxonomy of the genus Talaromyces. Stud. Mycol. 2014, 78, 175-341. [CrossRef] [PubMed]

55. Chen, A.J.; Frisvad, J.C.; Sun, B.D.; Varga, J.; Kocsubé, S.; Dijksterhuis, J.; Kim, D.H.; Hong, S.B.; Houbraken, J.; Samson, R. Aspergillus section Nidulantes (formerly Emericella): Polyphasic taxonomy, chemistry and biology. Stud. Mycol. 2016, 84, 1-118. [CrossRef]

56. Vasilieva, A.A.; Chekunova, L.N.; Polyakova, A.V. Effect of temperature on growth and viability of Hormoconis resinae and Phialophora sp. developing in the aviation fuel. Mycol. Phytopatologiya 2009, 43, 312-316.

57. Wang, Y.; Tian, R.M.; Gao, Z.M.; Bougouffa, S.; Qian, P.-Y. Optimal eukaryotic 18 S and universal 16S/18S ribosomal RNA primers and their application in a study of symbiosis. PLoS ONE 2014, 9, e90053. [CrossRef]

58. Chekanov, K.; Kublanovskaya, A.; Lobakova, E. Eukaryotic sequences in the 16Sr RNA metagenomic dataset of algal-bacterial consortia of the White Sea coastal zone. J. Eukaryot. Microbiol. 2019, 66, 853-856. [CrossRef]

59. Bates, S.T.; Berg-lyons, D.; Caporaso, J.G.; Walters, W.A.; Knight, R.; Fierer, N. Examining the global distribution of dominant archaeal populations in soil. ISME J. 2010, 5, 908-917. [CrossRef] [PubMed]

60. Kublanovskaya, A.; Chekanov, K.; Solovchenko, A.; Lobakova, E. Cyanobacterial diversity in the algal-bacterial consortia from Subarctic regions: New insights from the rock baths at White Sea Coast. Hydrobiologia 2019, 830, 17-31. [CrossRef]

61. Caporaso, J.G.; Kuczynski, J.; Stombaugh, J.; Bittinger, K.; Bushman, F.D.; Costello, E.K.; Fierer, N.; Peña, A.G.; Goodrich, J.K.; Gordon, J.I.; et al. QIIME allows analysis of high-throughput community sequencing data. Nat. Methods 2010, 7, 335-336. [CrossRef] [PubMed]

62. Altschul, S.F.; Madden, T.L.; Schäffer, A.A.; Zhang, J.; Zhang, Z.; Miller, W.; Lipman, D.J. Gapped BLAST and PSI-BLAST: A new generation of protein database search programs. Nucleic Acids Res. 1997, 25, 3389-3402. [CrossRef] [PubMed] 
63. Huse, S.M.; Welch, D.B.M.; Voorhis, A.; Shipunova, A.; Morrison, H.G.; Eren, A.M.; Sogin, M.L. VAMPS: A website for visualization and analysis of microbial population structures. BMC Bioinform. 2014, 15, 41. [CrossRef] [PubMed]

64. Beccati, A.; Gerken, J.; Quast, C.; Yilmaz, P.; Glöckner, F.O. SILVA tree viewer: Interactive web browsing of the SILVA phylogenetic guide trees. BMC Bioinform. 2017, 18, 433. [CrossRef]

65. Gaylarde, C.C.; Bento, F.M.; Kelley, J. Microbial contamination of stored hydrocarbon fuels and its control. Rev. Microbiol. 1999, 30, 1-10. [CrossRef]

66. Rauch, M.E.; Graef, H.W.; Rozenzhak, S.M.; Jones, S.E.; Bleckmann, C.A.; Kruger, R.L.; Naik, R.R.; Stone, M.O. Characterization of microbial contamination in United States Air Force aviation fuel tanks. J. Ind. Microbiol. Biotechnol. 2006, 33, 29-36. [CrossRef]

67. Yemashova, N.A.; Murygina, V.P.; Zhukov, D.V.; Zakharyantz, A.A.; Gladchenko, M.A.; Appanna, V.; Kalyuzhnyi, S.V. Biodeterioration of crude oil and oil derived products: A review. Rev. Environ. Sci. Bio Technol. 2007, 6, 315-337. [CrossRef]

68. Martin-Sanchez, P.M.; Becker, R.; Gorbushina, A.A.; Toepel, J. An improved test for the evaluation of hydrocarbon degradation capacities of diesel-contaminating microorganisms. Int. Biodeterior. Biodegrad. 2018, 129, 89-94.

69. Korshunova, T.; Chetverikov, S.; Bakaeva, M.; Kuzina, E.; Rafikova, G.; Chetverikova, D.; Loginov, O. Microorganisms in the elimination of oil pollution consequences. Appl. Biochem. Microbiol. 2019, 55, 344-354. [CrossRef]

70. Mitchell, R.; Alexander, M. Lysis of soil fungi by bacteria. Can. J. Microbiol. 1963, 9, 169-177. [CrossRef]

71. Balachandran, C.; Duraipandiyan, V.; Balakrishna, K.; Ignacimuthu, S. Petroleum and polycyclic aromatic hydrocarbons (PAHs) degradation and naphthalene metabolism in Streptomyces sp. (ERI-CPDA-1) isolated from oil contaminated soil. Bioresour. Technol. 2012, 112, 83-90. [CrossRef] [PubMed]

72. Liu, R.; Zhang, Y.; Ding, R.; Li, D.; Gao, Y.; Yang, M. Comparison of archaeal and bacterial community structures in heavily oil-contaminated and pristine soils. J. Biosci. Bioeng. 2009, 108, 400-407. [CrossRef]

73. Tapilatu, Y.H.; Grossi, V.; Acquaviva, M.; Militon, C.; Bertrand, J.C.; Cuny, P. Isolation of hydrocarbon-degrading extremely halophilic archaea from an uncontaminated hypersaline pond (Camargue, France). Extremophiles 2010, 14, 225-231. [CrossRef]

74. Le Borgne, S.; Paniagua, D.; Vazquez-Duhalt, R. Biodegradation of organic pollutants by halophilic bacteria and archaea. J. Mol. Microbiol. Biotechnol. 2008, 15, 74-92. [CrossRef]

75. Baoune, H.; El Hadj-Khelil, A.O.; Pucci, G.; Sineli, P.; Loucif, L.; Polti, M.A. Petroleum degradation by endophytic Streptomyces spp. isolated from plants grown in contaminated soil of southern Algeria. Ecotoxicol. Environ. Saf. 2018, 147, 602-609. [CrossRef]

76. Chen, J.; Huang, P.T.; Zhang, K.Y.; Ding, F.R. Isolation of biosurfactant producers, optimization and properties of biosurfactant produced by Acinetobacter sp. from petroleum-contaminated soil. J. Appl. Microbiol. 2012, 112, 660-671. [CrossRef]

77. Yanan, W.; Yingying, L.; Jianliang, X.; Ke, S.; Yu, G.; Xiaolong, X. Exploring the degradation potential of Halomonas bacteria from oil-contaminated marine environment. China Pet. Process. Petrochem. Technol. 2018, 20, 91-98.

78. Bianciotto, V.; Bandi, C.; Minerdi, D.; Sironi, M.; Tichy, H.V.; Bonfante, P. An obligately endosymbiotic mycorrhizal fungus itself harbors obligately intracellular bacteria. Appl. Environ. Microbiol. 1996, 62, 3005-3010.

79. Pion, M.; Spangenberg, J.E.; Simon, A.; Bindschedler, S.; Flury, C.; Chatelain, A.; Bshary, R.; Job, D.; Junier, P. Bacterial farming by the fungus Morchella crassipes. Proc. R. Soc. B Biol. Sci. 2013, 280, 20132242. [CrossRef] [PubMed]

80. Haq, I.U.; Graupner, K.; Nazir, R.; van Elsas, J.D. The genome of the fungal-interactive soil bacterium Burkholderia terrae BS001-A plethora of outstanding interactive capabilities unveiled. Genome Biol. Evol. 2014, 6, 1652-1668. [CrossRef] [PubMed]

81. Abbasian, F.; Lockington, R.; Mallavarapu, M.; Naidu, R. A comprehensive review of aliphatic hydrocarbon biodegradation by bacteria. Appl. Biochem. Biotechnol. 2015, 176, 670-699. [CrossRef] [PubMed]

82. Young, D.; Rice, J.; Martin, R.; Lindquist, E.; Lipzen, A.; Grigoriev, I.; Hibbett, D. Degradation of bunker C fuel oil by white-rot fungi in sawdust cultures suggests potential applications in bioremediation. PLoS ONE 2015, 10, e0130381. [CrossRef]

83. Johnsen, A.R.; Wick, L.Y.; Harms, H. Principles of microbial PAH-degradation in soil. Environ. Pollut. 2005, 133, 71-84. [CrossRef]

84. Seneviratne, G.; Zavahir, J.S.; Bandara, W.M.M.S.; Weerasekara, M.L.M.A.W. Fungal-bacterial biofilms: Their development for novel biotechnological applications. World J. Microbiol. Biotechnol. 2008, 24, 739-743. [CrossRef]

85. Costerton, J.W.; Lewandowski, Z.; DeBeer, D.; Caldwell, D.; Korber, D.; James, G. Biofilms, the customized microniche. J. Bacteriol. 1994, 176, 2137. [CrossRef]

86. Herath, H.M.L.I.; Rajapaksha, A.U.; Vithanage, M.; Seneviratne, G. Developed fungal-bacterial biofilms as a novel tool for bioremoval of hexavelant chromium from wastewater. Chem. Ecol. 2014, 30, 418-427. [CrossRef]

87. Pandit, A.; Adholeya, A.; Cahill, D.; Brau, L.; Kochar, M. Microbial biofilms in nature: Unlocking their potential for agricultural applications. J. Appl. Microbiol. 2020, 129, 199-211. [CrossRef] 